\title{
Penerapan Sistem Informasi Geografis dalam Pemetaan Sebaran Kasus Gizi Buruk
}

\author{
Aris Sudianto ${ }^{1}$, Muhammad Wasil2, Mahpuz ${ }^{3}$ \\ 1,2,3 Program Studi Teknik Informatika, Universitas Hamzanwadi \\ *sudianto166@gmail.com
}

\begin{abstract}
Abstrak
Gizi Buruk atau Malnutrisi merupakan suatu istilah umum yang merujuk pada suatu kondisi medis yang disebabkan oleh diet yang tidak tepat atau tidak cukup. Penyebab utama dari gizi buruk adalah kurangnya anakanak dalam memperoleh makanan dengan kandungan energi dan protein yang cukup. Hal ini dikaitkan dengan tingkat ekonomi masyarakat. Selain itu kurangnya pengetahuan orang tua akan pentingnya nutrisi bagi tumbuh kembang anak. Di Lombok Timur, kasus gizi buruk setiap tahunnya selalu muncul, namun baru-baru ini pada tahun 2019 ditemukan kembali kasus Gizi buruk yang ironisnya selalu terlambat diketahui. hal ini dikarenakan lokasi penderita gizi buruk tidak terjangkau atau bahkan tidak diketahui oleh pemerintah kabupaten, hal inilah yang membuat penanganan kasus Gizi Buruk di kabupaten lombok timur terlambat ditangani, yang tidak jarang mengakibatkan kematian pada bayi dan anak - anak. untuk itu pada penelitian kali ini peneliti mengangkat tema tentang bagaimana memetakan sebaran lokasi kasus gizi buruk yang tersebar di kabupaten lombok timur, tujuan dari penelitian ini adalah untuk membantu pemerintah kabutapen Lombok Timur guna mengetahui lokasi penderita Gizi Buruk. Metode penelitian yang dilakukan adalah dengan mencatat langsung titik koordinat dari lokasi penderita giz buruk. dengan adanya aplikasi ini dapat membantu pemerintah dalam mengetahui lokasi kasus gizi buruk di kabupaten lombok timur..
\end{abstract}

Kata Kunci : Malnutrisi, Gizi buruk, lombok timur, pemetaan, sebaran, lokasi

\begin{abstract}
Malnutrition or Malnutrition is a general term that refers to a medical condition caused by an improper or inadequate diet. The main cause of malnutrition is the lack of children in getting enough energy and protein foods. This is with the economic level of the community. In addition, for parents' knowledge about the importance of nutrition for child development. In East Lombok, cases of malnutrition always appear every year, but recently in 2019, cases of malnutrition were rediscovered which ironically was always known too late. This is because the location of malnutrition sufferers is not reachable or is not known by the district government, this is what makes the handling of malnutrition cases in East Lombok district late, which often results in deaths of infants and children. For this reason, in this study the researcher raised the theme of how to map the distribution of the location of well-known cases of malnutrition in East Lombok district. The purpose of this study was to help the East Lombok fogapen government to see the location of people with malnutrition. The research method used is to directly record the coordinates of the location of people with bad nutrition. with this application, it can help the government in alerting the location of cases of malnutrition in East Lombok district..
\end{abstract}

Keywords: Malnutrition, malnutrition, East Lombok, mapping, distribution, location

\section{Pendahuluan}

Lombok Timur merupakan salah satu

Kabupaten yang berada di Provinsi Nusa

Tenggara Barat yang terletak di sebelah Timur
Pulau Lombok, Kabupaten Lombok Timur memiliki luas $1.605,55 \mathrm{~km} 2$ dengan populasi 1.105.582 jiwa. Gizi Buruk / Malnutrisi merupakan suatu istilah umum yang merujuk 
pada suatu kondisi medis yang disebabkan oleh diet yang tidak tepat atau tidak cukup[1]. Walaupun seringkali disamakan dengan kurang gizi yang disebabkan oleh kurangnya konsumsi, buruknya absorpsi, atau kehilangan besar nutrisi atau gizi. Gizi buruk biasanya menyerang anak - anak, menurut Badan Kesehatan Dunia (WHO) lebih dari 54 Persen balita meninggal dunia akibat gizi buruk. Penyebab utama dari gizi buruk adalah kurangnya balita atau anakanak dalam memperoleh makanan dengan kandungan energi dan protein yang cukup. Hal ini dikaitkan dengan tingkat ekonomi masyarakat. Selain itu kurangnya pengetahuan orang tua akan pentingnya nutrisi bagi tumbuh kembang anak. Gizi buruk tidak terjadi secara langsung, kondisi ini berlangsung secara bertahap. Oleh karenanya, gizi buruk sebenarnya dapat diatasi jika ada pemahaman soal hal tersebut[2]..

Provinsi Nusa Tenggara Barat kasus Gizi buruk pada balita dan anak - anak tiap tahunnya selalu meningkat, angka kasus gizi buruk pada tahun 2018 meningkat sebanyak 217 kasus yang ditemukan di 10 kabupaten/kota, tercatat pada tahun 2017 kasus gizi buruk di NTB sekitar 187 kasus. Sedangkan pada 2018 meningkat menjadi 217 kasus. hal ini menjadi perhatian yang serius yang harus segera ditangani oleh pemerintah provinsi NTB, penyebab gizi buruk tersebut banyak cacat bawaan seperti jantung, bocor jantung, Pneumonia Berat. Meningitis, Hepatitis, ISPA, Epilepsi, Paru, Cerebral Palsy, Bronchitis Akut, Diare, Anemia dan lainnya. Di Kabupaten Lombok Timur, kasus gizi buruk setiap tahunnya memang selalu muncul, namun baru baru ini pada tahun 2019 ditemukan kembali kasus Gizi buruk yang ironisnya selalu terlambat diketahui oleh pemerintah daerah, bahkan tidak jarang kasus tersebut banyak diketahui dari media sosial yang beredar di masyarakat, hal ini menjadi pukulan berat bagi pemerintah daerah dalam upaya memerangi gizi buruk pada anak, susahnya mendapatkan informasi secara cepat menjadi kelemahan pemerintah daerah untuk dapat mengetahui secara cepat lokasi terdampak gizi buruk. Lokasi yang terbilang jauh dari pusat kota, lokasi yang terpencil, serta lokasi yang jarang dikunjungi oleh pemerintah daerah merupakan lokasi - lokasi yang rawan terkena gizi buruk, hal ini berdampak pada jumlah kasus Gizi Buruk yang setiap tahunnya selalu meningkat di Kabupaten Lombok Timur. Dikarenakan lokasi yang tidak diketahui secara cepat oleh pemerintah daerah kabupaten lombok timur membuat penanganan kasus Gizi Buruk di kabupaten lombok timur terlambat ditangani, yang tidak jarang mengakibatkan kematian pada bayi dan anak - anak. 
e-ISSN 2614-8773

DOI : $10.29408 / j i t . v 4 i 2.3559$

Link : https://dx.doi.org/10.29408/jit.v4i2.3559

Peran dari teknologi informasi dalam memberikan akses untuk semua informasi sangatlah penting, hal ini terlihat semakin banyaknya masyarakat yang menggunakan teknologi sebagai wadah untuk mencari informasi secara cepat dan tepat, website sebagai media penghubung sangat berperan penting dalam proses penyebaran informasi, hal ini dikarenakan website juga bisa digunakan sebagai sarana promosi yang sangat efektif[3]. Sistem Informasi Geografis merupakan suatu wadah yang dapat membantu pengguna dalam menemukan lokasi yang tersebar di berbagai tempat berbasis peta digital. Untuk itu pada penelitian kali ini peneliti mengangkat tema tentang bagaimana memetakan sebaran lokasi kasus gizi buruk yang tersebar di kabupaten lombok timur, dengan tujuan untuk membuat suatu produk yang dapat memetakan sebaran lokasi terdampak gizi buruk di kabupaten lombok timur, dengan harapan dapat membantu pemerintah dalam mengetahui lokasi kasus gizi buruk di kabupaten lombok timur secara cepat dan akurat, sehingga untuk kedepannya pemerintah dapat mengetahui lokasi mana saja yang ada di Kabupaten Lombok Timur yang terdapat kasus Gizi Buruk. Teknologi website menjadi sangat penting untuk bisa mewujudkan informasi yang dapat diakses dengan cepat dan mudah oleh masyarakat luas, teknologi website dapat menjadi suatu pondasi untuk menyebarkan informasi secara cepat dan akurat, sehingga dengan adanya sistem informasi ini, dapat mempercepat proses penyelesaian pekerjaan dalam mengolah data yang ada agar lebihakurat, efektif dan efisien sehingga dapat menghemat waktu dan meningkatkan kinerja[4], [5]. Terdapat kasus gizi buruk yang mengakibatkan pasien meninggal padahal jarak pasien kurang dari 1 kilo meter dari tempat pelayanan kesehatan rumah sakit, seharusnya hal ini tidak terjadi, sehingga diharapkan dengan melakukan Pemetaan kasus gizi buruk melalui Sistem Informasi Geografis (SIG) akan memudahkan pihak Dinas Kesehatan dan puskesmas puskesmas dalam melakukan intervensi untuk penanggulangan gizi buruk[6]. Dengan adanya aplikasi sistem informasi diharapkan dapat membantu dalam meningkatkan potensi menjadi lebih baik lagi. Dapat disimpulkan bahwa peranan teknologi informasi, khususnya teknologi pemetaan berbasis SIG menjadi sangat penting untuk mempermudah masyarakat mengetahui dengan cepat informasi terkini yang sedang terjadi dan lokasi kejadian secara cepat dan tepat. Selain itu Dengan adanya aplikasi berbasis sistem informasi geografis pencarian lokasi dapat lebih cepat dan efisien waktu[7], [8]. Terdapat pengaruh bermakna antara pemanfaatan pelayanan, penyakit infeksi, pola asuh makan, pendapatan 
keluarga, pengetahuan, dan pekerjaan ibu terhadap status gizi buruk pada anak $6-24$ bulan. Tidak ada pengaruh antara pendidikan ibu, jumlah anggota keluarga, pola asuh kesehatan, pola makan, sanitasi lingkungan, dan keterpaparan informasi terhadap status gizi buruk anak 6 - 24 bulan[9]. Hal ini juga menjadi penentu bahwa gizi buruk terjadi dikarenakan faktor lingkungan dan pola asuh keluarga.

\section{Tinjauan Pustaka}

\subsection{Penelitian Terkait}

Menurut Aris Sudianto dalam penelitiannya yang tentang penerapan sistem informasi geografis untuk pemetaan kerajinan kain tenun dan gerabah, dengan dibangunnya aplikasi sistem informasi geografis untuk pemetaan lokasi kerajinan kain tenun dan gerabah di kabupaten lombok timur, diharapkan dapat membantu dalam meningkatkan potensi kerajinan yang ada di kabupaten lombok timur khususnya kerajinan kain tenun dan gerabah menjadi lebih baik lagi. Sehingga dapat membuat kerajinan kain tenun dan gerabah dapat kembali bersaing dengan kerajinan lain yang tersebar di daerah - daerah lain[10].
Dengan sistem informasi geografis banyak hal yang dapat dilakukan terutama dalam hal pemetaan, teknologi GIS ini dapat di manfaatkan untuk memajukan para pelaku usaha kecil menengah terutama dari segi informasi lokasi seperti halnya Usaha bengkel tambal ban yang sangat butuh sentuhan teknlologi agar keberadaan usaha tersebut lebih diketahui oleh masyarakat luas, jumlah bengkel tambal ban yang begitu banyak tersebar di kecamatan selong membuat usaha ini perlu mendapat perhatian lebih, mengingat jenis usaha ini memiliki peran yang sangat penting kelancaran transportasi masyarakat. Untuk itulah peran dari teknologi sangatlah penting untuk dapat membuat para pelaku usaha ini bisa terus maju dalam memajukan usaha Tambal ban.[7]

\subsection{Landasan Teori}

\section{Peta dan Pemetaan Posisi}

Menurut ICA (International Cartographic Association) Peta adalah gambaran atau representasi unsur-unsur ketampakan abstrak yang dipilih dari permukaan bumi yang ada kaitannya dengan permukaan bumi atau bendabenda angkasa, yang pada umumnya digambarkan pada suatu bidang datar dan diperkecil/diskalakan. Sehingga bisa disimpulkan oleh peneliti bahwa peta merupakan bentuk penyajian sumber informasi mengenai suatu permukaan bumi yang dapat digunakan bagi para perncana untuk pengambilan keputusan. 
Sedangkan pemetaan merupakan Proses pengukuran ,perhitungan dan penggambaran permukaan bumi dengan menggunakan cara atau metode tertentu sehingga didapatkan hasil berupa Softcopy dan Hardcopy atau bisa juga diartikan sebagai penyajian data dan informasi tentang gambaran permukaan bumi.

\section{Sistem Informasi Geografi (GIS)}

Sistem informasi geografis (SIG) adalah sebuah sistem atau teknologi berbasis komputer yang dibangun dengan tujuan untuk mengumpulkan, menyimpan, mengolah dan menganalisa, serta menyajikan data dan informasi dari suatu obyek atau fenomena yang berkaitan dengan letak atau keberadaannya di permukaan bumi.[4] Sistem Informasi Geografis merupakan paket software terintegrasi yang dibuat secara khusus untuk mengolah data geografis dengan berbagai keperluan

\section{Konsep Dasar Sistem Informasi Geografi}

SIG dapat menyajikan real world (dunia nyata) pada monitor sebagaimana lembaran peta dapat merepresentasikan dunia nyata di atas kertas. Tetapi, SIG memiliki kekuatan lebih dan fleksibilitas dari pada lembaran pada kertas. Peta merupakan representasi grafis dari dunia nyata, obyek-obyek yang dipresentasikan di atas peta disebut unsur peta atau map features (contohnya adalah sungai, taman, kebun, dan jalan). Karena peta mengorganisasikan unsurunsur berdasarkan lokasi-lokasinya.

\section{Kemampuan SIG}

Sistem informasi geografis mempunyai kemampuan untuk menghubungkan berbagai data pada suatu titik tertentu di bumi, menggabungkannya, menganalisis dan akhirnya memetakan hasilnya:

a. Memasukkan dan mengumpulkan data geografis (spasial dan atribut).

b. Mengintegrasikan data geografis.

C. Memeriksa, meng-update (meng-edit) data geografis.

d. Menyimpan atau memanggil kembali data geografis.

e. Mempresentasikan atau menampilkan data geografis.

f. Mengelola, memanipulasi dan menganalisis data geografis.

g. Menghasilkan output data geografis dalam bentuk peta tematik (view dan layout), tabel, grafik (chart) laporan, dan lainnya baik dalam bentuk hardcopy maupun softcopy

\subsection{Tahapan Penelitian}

Adapun tahapan dari penelitian ini meliputi beberapa tahapan diantaranya : 
DOI : $10.29408 / j i t . v 4 i 2.3559$
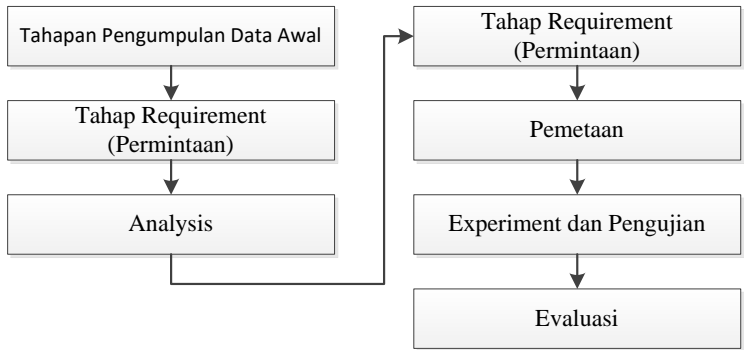

Gambar 1. Tahapan Penelitian

1. Tahap pengumpulan informasi mengenai data - data ketersebaran dari sebaran kasus gizi buruk di kecamatan selong yang dalam hal ini informasi yang dibutuhkan di dapat dari pengamatan langsung di lapangan

2. Tahap Requirement ( Permintaan ) Pada tahapan requirement (permintaan) ini ditujukan untuk dapat mengarahkan para penderita kasus gizi buruk. Pada tahapan ini dilakukan penyaringan penderita mana saja yang akan di jadikan calon atau kandidat requirement.

3. Analisis Pada tahap analisis ini bertujuan untuk mendapatkan suatu pemahaman secara menyeluruh terhadap penerapan sistem informasi geografi yang akan dilakukan, berdasarkan letak posisi sebaran kasus gizi buruk.

4. Pemetaan. Pada tahapan pemetaan ini, dilakukan suatu proses pemetaan lokasi dari setiap kasus gizi buruk secara menyeluruh. Pada tahapan ini dilakukan proses penentuan lokasi, penyimpanan dari setiap penderita kasus gizi buruk dengan menggunakan teknologi / alat pencatatan lokasi.
5. Experimen dan Pengujian Hasil Pemetaan yang telah dilakukan, di uji coba untuk melihat apakah pemetaan yang dilakukan dapat sesuai dengan yang diinginkan peneliti.

6. Evaluasi hasil experimen dan pengujian. Setelah dilakukan pengujian dan experimen terhadap hasil pemetaan yang dilakuan, maka bisa dilihat perbedaan dari hasil yang dilakukan sebelumnya.

\section{Metode Penelitian}

\subsection{Metodologi Dalam Pembangunan Sistem} Informasi Geografis (GIS)

Beberapa tahapan yang dapat digunakan untuk pengaplikasian metodologi sistem informasi geografi (GIS) yaitu sebagai berikut :

1. Pendefinisian permasalahan dengan melalui suatu pendekatan yaitu pengumpulan data skunder seperti pengumpulan data dan informasi lokasi berupa peta dasar.

2. Tahapan kedua yakni melakukan analisis untuk menentukan lokasi penderita gizi buruk yang akan di petakan.

3. Tahapan ketiga yakni melakukan pencatatan titik koordinat dari masing masing lokasi penderita gizi buruk untuk disimpan sebagai lokasi pemetaan menggunakan alat pencatat koordinat. 


\subsection{Lokasi Penelitian}

Penelitian ini dilakukan dengan mengumpulkan sumber data yang di ambil dengan cara melakukan pencataan titik koordinat dari setiap lokasi penderita gizi buruk yang tersebar di seluruh Kabupaten Lombok Timur.

\subsection{Pengumpulan Bahan}

Alat dan bahan yang digunakan untuk menunjang kesuksesan dari penelitian ini adalah antara lain, Buku yang digunakan untuk mencatat secara manual setiap titik koordinasi dari setiap lokasi penderita gizi buruk, Laptop sebagai alat untuk merancang software yang digunakan sebagai media untuk menampung dan melihat lokasi penderita gizi buruk, FlashDisk sebagai media penyimpanan data, Kamera Digital yang digunakan untuk mengambil gambar dari lokasi kerajinan, GPS atau Alat pencatat Koordinat, yang digunakan untuk mencatat setiap titik koordinat dari lokasi penderita gizi buruk sebelum di masukkan/entry ke dalam software khusus yang dibuat.

\section{Hasil dan Pembahasan}

Aplikasi pemetaan Lokasi Penderita Gizi Buruk berbasis GIS telah dilakukan dengan mengambil contoh penginputan data titik koordinat dari suatu lokasi dan menampilkan hasilnya menjadi suatu bentuk hasil pemetaan yang dapat di lihat dengan menggunakan bantuan jaringan internet.
Dari hasil uji coba Aplikasi ini masih menggunakan data sembarang yang di buat oleh peneliti, ini disebabkan data yang sebenarnya masih belum di dapatkan yang terbaik, sehingga masih membutuhkan pengolahan data kembali. Adapun hasil dari uji coba aplikasi pemetaan adalah sebagai berikut :

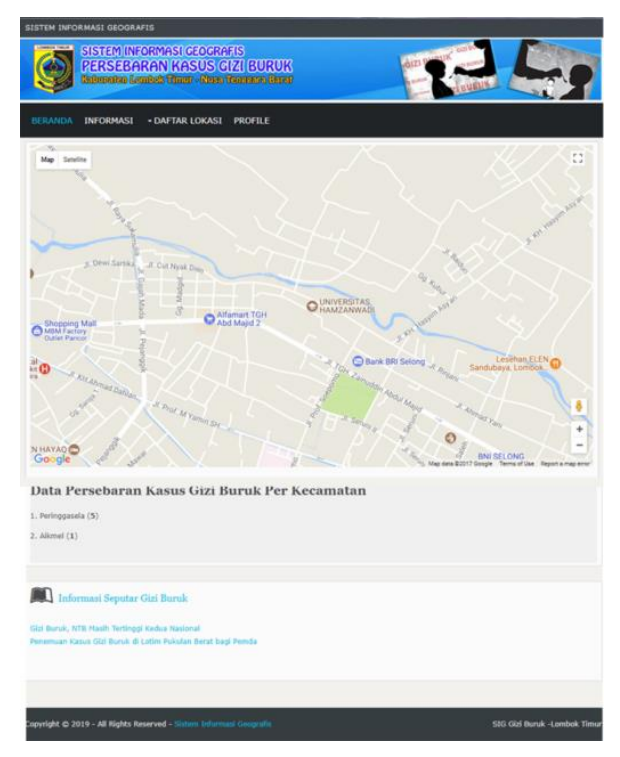

Gambar 1. Halaman Beranda Aplikasi

Pemetaan

Halaman utama saat aplikasi pemetaan di akses oleh pengguna, dimana pada bagian ini informasi Seputar Gizi Buruk beserta pemetaan dapat dilihat oleh pengunjung, sehingga dapat lebih memudahkan pengguna untuk mengetahui secara cepat informasi seputar gizi buruk yang diinginkan, terutama yang tersebar di kabupaten lombok timur. Pada halaman utama ini pengunjung dapat melihat daftar lokasi penderita gizi buruk dengan memilih menu yang telah tersedia, selain itu pengunjung jg dapat melihat peta untuk masing - masing penderita gizi buruk, 
dan juga melihat semua sebaran lokasi penderita gizi buruk secara langsung.

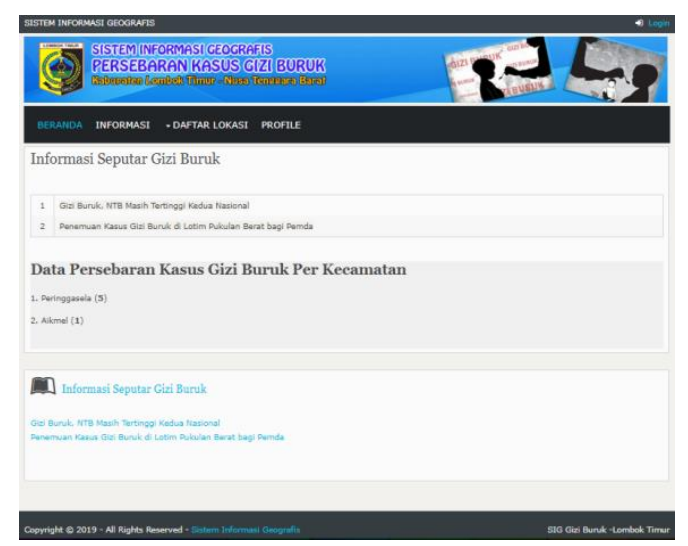

Gambar 2. Halaman Daftar Informasi seputar Gizi Buruk

\section{Kesimpulan}

Dari paparan hasil penelitian di atas dapat ditarik suatu kesimpulan antara lain sebagai berikut :

- Dari hasil pemetaan yang dilakukan oleh peneliti, dapat disimpulkan bahwa potensi terjadinya kasus gizi buruk di kabupaten lombok timur terus meningkat dari tahun ke tahun, hal ini terlihat dari jumlah data yang telah di survey oleh peneliti yang tersebar di kabupaten lombok timur, dimana data di ambil dari Dinas terkait..

- Banyaknya kendala yang dihadapi oleh petugas kesehatan menyebabkan jumlah penderita gizi buruk terus meningkat.

- Data yang di dapat dari Dinas terkait untuk jumlah penderita gizi buruk disetiap kecamatan di wilayah kabupaten lombok timur belum maksimal..

\section{Daftar Pustaka}

[1] S. Ariana, "Hubungan Status Gizi dengan Kejadian Pneumonia," Artik. Penelit., pp. 1-12, 2015.

[2] H. Isnaniah, Nirwana, and A. Rizani, "Hubungan Status Gizi dengan Perkembangan Fisik Balita di Wilayah Kerja Puskesmas Sebatung Kotabaru Tahun 2014," Jur. Kebidanan Poltekkes Banjarmasin, vol. 6, no. 38, pp. 146-154, 2015.

[3] Sudianto Aris, "Penerapan Website Sebagai Sarana Promosi Wisata Budaya pada Kabupaten Lombok Timur," Infotek J. Inform. dan Teknol., vol. 1Sudianto, no. 1, pp. 11-17, 2018.

[4] A. Sudianto and H. Ahmadi, "Rancang Bangun Sistem Informasi Penjualan Sparepart Motor Pada Bengkel Vinensi Motor Berbasis Web Guna Meningkatkan Penjualan dan Promosi Produk Pendahuluan Vinensi sepeda motor motor," Infotek J. Inform. dan Teknol., vol. 3, no. 2, pp. 32-39, 2020.

[5] A. Sudianto and J. Sugiantara, "Website as Foundation Information Media under the auspices of Nahdlatul Wathan," $J$. 
Phys. Conf. Ser., vol. 1539, no. 1, pp. 38 , 2020, doi: 10.1088/17426596/1539/1/012024.

[6] M. S. Wulandari and R. Noveandini, "Digitalisasi Pemetaan Ukm Tenun Garut Berbasis Sistem Informasi Geografis Sebagai Media Komunikasi Dan Pemasaran Produk Lokal," vol. 1-10, pp. 978-979, 2013.

[7] L. K. W. Sudianto Aris, Nurhidayati, "Penerapan Sistem Informasi Geografis Untuk Pemetaan Bengkel Tambal Ban di Kecamatan Selong Kabupaten Lombok Timur," Infotek J. Inform. dan Teknol., vol. 3, no. 1, pp. 51-57, 2020, doi: 10.1029/2019GH000237.

[8] M. Saiful and S. Aris, "Penerapan Sistem Informasi Tracer Study untuk Mengetahui Tingkat Kontribusi Perguruan Tinggi dengan Kompetensi Lulusan ( Studi Kasus Fakultas Teknik Universitas Hamzanwadi )," J. Inform. dan Teknol., vol. 2, no. 1, pp. 43-52, 2019.

[9] E. Kusumawati and S. Rahardjo, "Pengaruh Pelayanan Kesehatan terhadap Gizi Buruk Anak Usia 6 _ 24 Bulan," Kesmas Natl. Public Heal. J., vol. 6 , no. 4, p. 158, 2012, doi: 10.21109/kesmas.v6i4.93.

[10] S. M. Sudianto Aris, "Penerapan Sistem Informasi Geografis (GIS) dalam Pemetaan Kerajinan Kain Tenun dan Gerabah untuk Meningkatkan Potensi Kerajinan di Kabupaten Lombok Timur," Infotek J. Inform. dan Teknol. J. Inform. dan Teknol., vol. 1, no. 2, pp. 64-71, 2018.

[11] Hariman Bahtiar; Muhamad Wasil; Bambang Harianto, "Digitalisasi Karya TGKH. Muhammad Zainuddin Abdul Madjid berbasis mobile sebagai media pembelajaran interaktif untuk pelestarian peninggalan pendiri Nahdlatul Wathan," Infotek J. Inform. dan Teknol., vol. 88, no. 5, pp. 427-434, 2019.

[12] H. Bahtiar, A. E. Sutriadi, M. Djamaluddin, and T. Barat, "Digitalisasi Kitab Nadham Batu Ngompal Karya TGKH . Muhammad Zainuddin Abdul Madjid Berbasis OPF Flipbook Pulau Lombok sebagai salah satu pulau yang mempunyai potensi yang cukup besar untuk dijadikan objek wisata

Dengan keindahan alam dan keanekaragaman," Infotek J. Inform. dan Teknol., vol. 3, no. 2, pp. 1-8, 2020

[13] Hariman Bahtiar; Muhamad Wasil; Bambang Harianto, "Digitalisasi Karya TGKH. Muhammad Zainuddin Abdul Madjid berbasis mobile sebagai media pembelajaran interaktif untuk pelestarian peninggalan pendiri Nahdlatul Wathan," Infotek J. Inform. dan Teknol., vol. 88, no. 5, pp. 427-434, 2019.

[14] H. Bahtiar and L. Kerta Wijaya, "Mobile Based Geographic Information System for mapping and data collection Towards 4.0 Industry," J. Phys. Conf. Ser., vol. 1539, no. 1 , pp. 0-5, 2020.

[15] Aris Sudianto and L. M. Samsu, "Penerapan Media Pembelajaran Interaktif Pelajaran Bahasa Indonesia Berbasis Android Untuk Kelas Vii Madrasah Tsanawiyah Nahdlatul Wathan Ketangga Sebagai Upaya Untuk Peningkatkan Minat Belajar Siswa," vol. 2, no. 2, pp. 5-10, 2019. 